\title{
Considerations on extinct species of Brazilian flora
}

\author{
Thiago Serrano de Almeida Penedo ${ }^{4,6}$, Miguel d'Ávila de Moraes ${ }^{5}$, Rafael Augusto Xavier Borges ${ }^{2}$, Daniel \\ Maurenza ${ }^{1}$, Diogo Marcilio Judice ${ }^{1}$, Gustavo Martinelli ${ }^{1,3}$
}

\begin{abstract}
Extinction risk assessments are important tools for plant conservation. However, misinterpretations can lead to negative consequences for survival of species. Inconsistent categorization as extinction, when the species is still extant, constitutes a Romeo error, and annuls all and any mechanism of existing legal protection. But precisely determining the extinction of a plant species is a challenging task, in that the plants can portray characteristics that permit survival in a state of dormancy. To circumvent this problem, specialists frequently adopt precaution and a comprehensive approach that consider biological, ecological, and geographical parameters as inputs for the assessments. It is also important to include explicit logic arguments, as building-blocks of the rational that will support the assessment. Transparent interpretation of the available data can minimize inconsistent categorization. In Brazil, 23\% of the plant species assessed as Extinct or Extinct in the Wild, comprise Romeo errors. The other $77 \%$ are cases of Data Deficient. Countries that succeeded in minimizing problems arising from this error developed specific legislation to protect threatened species, including mechanisms to annul an erroneous categorizations. Anyhow, the use of categories Extinct (EX) and Extinct in the Wild (EW) according to IUCN definitions should be avoided when no effort has been made to provide evidence of extinction in the wild.
\end{abstract}

Key words: Romeo error, legal protection; risk assessments.

Processes of extinction and appearance of new species are common and inherent to the Earth's geological and biological evolution. Paleontological studies show evidence of the occurrence of at least five major natural events of extinction (Leinz \& Amaral 1978). However, the current rates of extinction of species are commonly associated with threats arising from human activities (Hilton-Taylor 2009), in a large part related to the non-sustainable use of natural resources which results in the loss and degradation of habitats (Foley et al. 2005). The transformation of the landscape represents a stress factor in the dynamics and structure of populations (Tabarelli \& Gascon 2005), which can lead to the extinction of species. In this context, the monitoring of species extinction risk through official red lists allows the competent authorities to act in favor of conservation, facilitating actions that can ensure greater chances of survival for threatened species. Thus, extinction risk assessments can be an important conservation tool (Moraes \& Martinelli 2013). On the other hand, unfounded affirmations resulting from erroneous or inconsistent interpretations can lead to negative consequences, such as the annulment of all legal protection when a species is pointed as extinct, when still extant.

It is mainly government's mission to ensure the survival of threatened species, with the power to forbid or limit the extraction of these species from its native range, and to adopt compensating and mitigating measures to guarantee their conservation in areas where the vegetation is cut back for alternative land use (Brasil 2012). In Brazil an act

\footnotetext{
${ }^{1}$ Instituto de Pesquisas Jardim Botânico do Rio de Janeiro, Centro Nacional de Conservação da Flora (CNCFlora), PROBIO II, R. Pacheco Leão 915, 22460-030, Rio de Janeiro, RJ, Brazil.

${ }^{2}$ Universidade Federal do Rio Grande do Sul (UfRGS), Av. Bento Gonçalves, 9500, 91501-970, Campus do Vale, Bairro Agronomia, Porto Alegre, RS, Brazil.

${ }^{3}$ Instituto de Pesquisas Jardim Botânico do Rio de Janeiro, R. Pacheco Leão 915, 22460-030, Rio de Janeiro, Brazil.

${ }^{4}$ Escola Nacional de Botânica Tropical, Instituto de Pesquisas Jardim Botânico do Rio de Janeiro, R. Pacheco Leão 915, 22460-030, Rio de Janeiro, Brazil.

${ }^{5}$ União Internacional para a Conservação da Natureza - UICN, CLN 210, Asa Norte, 70.862-530, Brasília, DF, Brazil.

${ }^{6}$ Author for correspondence: serranoapenedo@gmail.com
} 
committed against threatened species is considered a federal crime and an aggravating circumstance in fixing the punishment (Brasil 1998). Beyond that, plant species assessed as threatened on the last national red list are guaranteed the creation and implementation of conservation action plans designed for their recovery (MMA 2008) and have priority with regard to federal financial support to measures such as ex situ conservation (Gonzales 2010). Endangered species also have priority in conservation actions foreseen in protected areas management plans (Brasil 2000).

But to put existent mechanisms of threatened species protection of the Brazilian legislation into practice, conceptual clarity and methodological transparency are needed in relation to the criteria employed. The system of categories and criteria for extinction risk assessment proposed by IUCN (2001), widely adopted around the world, considers a species as Extinct (EX) when there is absolutely no doubt that the last individual died, and Extinct in the Wild (EW), when a taxon is found only in cultivation, or as a naturalized population (or populations) outside its historic range (IUCN 2010). However, to determine the extinction of a taxon is extremely difficult (Diamond 1987), and demands the use of additional criteria, which besides taking into account only the collecting effort over a period of time, also consider the reproductive cycle and the species' life form, as well as their historical and potential distribution (IUCN 2010).

Nonetheless, in practice, it is impossible to be certain that the last individual of a plant species died - mainly in megadiverse countries such as Brazil, where extensive areas are insufficiently inventoried and several plant groups are understudied, which may lead to inconsistent extinction risk assessments. The erroneous classification of an organism as extinct is known as a Romeo error (Collar 1998). This type of error is especially common for flora species. Besides the existing knowledge gaps, plants can portray biological and ecological characteristics that permit its survival for decades in a dormant state, mainly in seed and seedling banks. In Brazil, about 23\% (3 in 13) of the species assessed as EX or EW in national red lists show Romeo errors (Martinelli \& Moraes 2013). Simaba floribunda A.St.-Hil. and Simaba suaveolens A.St.-Hil. (Simaroubaceae), were considered to be extinct in the second update of the national red list (IBAMA 1992). The categorization of those species was based on the criteria adopted by the Convention on International Commerce of Species of Wild Flora and Fauna in Danger of Extinction (CITES), which considered as extinct "those species not found in nature over the last 50 years" (IBAMA 1992). In the third update of the national red list (MMA 2008), the same species was considered Data Deficient, by having insufficient data for a consistent assessment. However, the increase in taxonomic and biogeographic studies revealed that currently $S$. floribunda has a wide geographic distribution, and occurs in nine states within the Mata Atlântica (Atlantic Forest) biome (Pirani \& Thomas 2013), having been reassessed as Least Concern (LC). Simaba suaveolens A.St-Hilaire, on the other hand, was reassessed as Critically Endangered (CR), as well as Actinocephalus cipoensis (Silveira) Sano, considered as Extinct in the Minas Gerais state red list (Mendonça \& Lins 2000) and on the national red list (MMA 2008), was rediscovered 99 years after its last recorded occurrence (Echternacht et al. 2010), and reassessed as Critically Endangered (CR) (Martinelli \& Moraes 2013).

The adoption of exclusively temporal criteria to determine the extinction of a taxon has already been shown to be insufficient, since numerous cases of rediscoveries recorded around the world show the subjectivity of these quantitative limits established arbitrarily (i.e., SANBI 2013; Ang et al. 2010; Lok et al. 2010; Lok et al. 2008; Dinter \& Greuter 2004; Lomelí-Sención \& SahagúnGodínez 2002). In Colombia, the species Solanum humboldtianum Granados-Tochoy \& S.Knapp (Solanaceae) was re-collected 200 years after it was last recorded (Granados-Tochoy et al. 2007). In India, Begonia tessaricarpa C.B.Clarke (Begoniaceae) was collected again a century after its last record (Ambrich \& Amadudin 2006), while in China the species of conifer Thuja sutchuenensis Franch, (Cupressaceae) considered Extinct in the Wild by IUCN, was rediscovered more than a century after its last record (Qiaoping et al. 2002).

In Brazil some cases of rediscovery of species in the wild were also documented. In São Paulo five species of the family Poaceae, considered as Probably Extinct on the state red list were rediscovered recently. The species Paspalum falcatum Nees ex Steud., Merostachys neesii Rupr. and Leersia ligularis Trin were collected during the building of the highway Rodoanel Mario Covas, while Gymnopogon burchellii (Munro 
ex Döll) Ekman and Ichnanthus bambusiflorus (Trin.) Döll were collected in floral surveys in the Serra da Bocaina (Filgueiras \& Shirasuna 2009). In Minas Gerais five species considered Probably Extinct on the state red list (Mendonça $\&$ Lins 2000) were re-collected in the wild after a directed effort in the field. The species Phlegmariurus ruber (Cham. \& Schltdl.) B.Øllg. (Lycopodiaceae), Paepalanthus argenteus var. elatus (Bong.) Hensold, P. stuetzelii Hensold, Comanthera circinnata (Bong.) L.R.Parra \& Giul. and Actinocephalus cipoensis (Eriocaulaceae) were rediscovered in Cadeia do Espinhaço (Echternacht et al. 2010; Vasconcelos et al. 2002), a highly visited area by botanists.

But the large majority (c. $77 \%-10$ in 13) of plant species assessed as EX (7) or EW (3) in national red lists possess insufficient data for a consistent assessments (Martinelli \& Moraes 2013). Only A. cipoensis, and Nidularium utriculosum Ule (Bromeliaceae) have been recorded over the last 50 years, while Cryptanthus fosterianus L.B.Sm., Neoregelia binotii (Antoine) L.B.Sm. (Bromeliaceae), Hindsia violacea Benth. (Rubiaceae), Isoetes bradei Herter (Isoetaceae), Ruellia chamaedrys (Nees) Angely (Acanthaceae), Solanun spissifolium Sendtn. (Solanaceae), Symplocos neglecta Brand and Symplocos altissima Brand (Symplocaceae) have very old records, sometimes represented just by the type collection and without a detailed description of the locality. Among the 10 species mentioned, efforts were made to collect new samples of Asplenium beckeri Brade (Aspleniaceae), H. violacea, and C. fosterianus. These efforts were unsuccessful and they were classified as Extinct in scientific publications (Siqueira-Filho \& Leme 2006; Sylvestre 2001; Di Maio 1996).

In many cases, the absence of precise information on the locality of the collecting areas described in herbarium records makes it difficult to determine their geographic distribution, as well as guiding field campaigns to obtain new samples. In other cases, the species are rare in the wild, making it difficult to obtain new records of occurrence. Such are the cases of S. altissima, N. utriculosum and A. cipoensis (Aranha Filho et al. 2009; Wanderley et al. 2009; Giulietti et al. 2009). The first is difficult to observe in situ (Aranha Filho 2006) while the second has type material collected in localities totally urbanized (Leme 2000), including a collection made in 1985 and considered doubtful, in the region near to the Tinguá Biological Reserve, and another in 1984 for the Santa Lúcia Biological Station, in the state of Espírito Santo (Martinelli \& Moraes 2013).

The low representation of herbarium records can also result in an imprecise or doubtful taxonomic definition, as observed for the species S. spissifolium, S. altissima, N. utriculosum e N. binotii, which show an insufficient quantity of samples collected to be able to obtain a precise taxonomic determination (Aranha Filho et al. 2007; Knapp 2002). The correct taxonomic determination of a certain species, its synonyms or even its hybrids, can generate significant alterations in the category of extinction risk in red lists (Kirschner \& Kaplan 2002).

Red lists should be supported by documented information, as recommended by IUCN (2001), so that the risk categories are employed correctly and the assessments consistency can be checked. Besides, the absence of explicit definitions, or the consideration of subjective criteria can generate erroneous assessments and/or inconsistent interpretation (Grammont \& Cuarón 2006). Furthermore, the absence of legal instruments to annul these erroneous assessments after rediscovers or new information leaves us as hostages of the slowness of the official national red listing process and risk of Romeo type errors. It is therefore necessary to review the Brazilian legal framework established for the protection of threatened species, in order to consider legal mechanisms to annul erroneous assessments more efficiently. Another desirable measure would be extension of the protection given to those in danger of extinction, to species assessed at EX or EW. In this way, Romeo errors would not imply negative consequences for the legal protection of species.

Countries where there is specific environmental legislation for the conservation of threatened species, such as Canada (Canadian Species at Risk Act 2002), South Africa (National Environment Management: Biodiversity Act 2004) and Australia (Threatened Species Legislation Amendment Act 2004) should be taken as models. In these countries there are mechanisms to make possible the immediate reinsertion of species on the red list after rediscovery in the wild, ensuring protection of the recently known populations.

In conclusion, the use of categories EX and EW should be avoided in doubtful cases where no exhaustive effort was made to find the species in the wild. As an alternative, a precautionary rating 
is recommended, and the category Critically Endangered should be used, adding an extra mark to the acronym CR (e.g. CR*) to denote that, besides being critically endangered, the species is probably extinct. This measure assure the permanence of species legal protection and the development of conservation actions at the same time (Martinelli \& Moraes 2013). Furthermore, applying the extra mark would help to reduce the uncertainties associated with the result contained on red lists (IUCN 2010; Staden et al. 2009). This recommendation was followed by the South African National Biodiversity Institute - SANBI), which through its program for monitoring endangered species of flora (Custodian of Rare and Endangered Wildflowers), rediscovered natural populations of 14 species considered $\mathrm{CR}^{*}$. This measure would also be appropriate for Brazil, in view of the recent cases of documented rediscoveries.

\section{References}

Ambrish, K. \& Amadudin, M. 2006. Rediscovery of an endemic and endangered plant (Begonia tessaricarpa C.B.Clarke) from Arunachal Pradesh, India, after a century. CurrentScience 91: 997.

Ang, W.F.; Lok, A.F.S.L. \& Tan, H.T.W. 2010. Rediscovery in Singapore of Pinanga simplicifrons (Miq.) Becc. (Arecaceae). Nature in Singapore 3: 83-86.

Aranha Filho, J.L.M. 2006. Revisão taxonômica da seção Neosymplocos Brand e considerações palinológicas das espécies brasileiras da seção Barberina (Vell.) A.DC. (Symplocos Jacq., Symplocaceae). Tese de Doutorado. Universidade Estadual de Campinas, Campinas.

Aranha Filho, J.L.M.; Fritsch, P.W.; Almeda, F \& Martins, A.B. 2007. A Revision of Symplocos Jacq. Section Neosymplocos Brand (Symplocaceae). Proceedings of the California Academy of Sciences 58: 407-446.

Aranha Filho, J.L.M.; Martins, A.B.; Fritsch, P.W. \& Almeda, F. 2009. Symplocaceae. In: Giulietti, A.M.; Rapini, A.; Andrade, M.J.G.; Queiroz, L.P. \& Silva, J.M.C. (eds.). Plantas raras do Brasil. Conservação Internacional, Universidade Estadual de Feira de Santana, Feira de Santana. Pp. 380-381.

Brasil. 1998. Lei de Crimes Ambientais, Lei n ${ }^{\circ} 9.605$, de 12 de fevereiro de 1998.

Brasil. 2000. Sistema Nacional de Unidades de Conservação - SNUC, Lei n ${ }^{\circ} 9.985$, de 18 de julho de 2000.

Brasil. 2012. Novo Código Florestal, Lei n ${ }^{\circ} 12.651$, de 25 de maio de 2012.

Biodiversitas. 2008. Boletim espécies ameaçadas online. Boletim $n^{\circ} 20$. Available in <http://www. biodiversitas.org.br>. Access on 13 June 2013.

Butchart, S.H.M.; Stattersfield, A.F. \& Brooks, T.M. 2006. Going or gone: defining 'Possibly Extinct' species to give a truer picture of recent extinctions. The Bulletin of the British Ornithologists's Club 126a: 7-24.

Collar, N.J. 1998. Extinction by assumption; or, the Romeo Error on Cebu. Oryx 32: 239-244.

Committee on the Status of Endangered Wildlife in Canada. 2011. Government of Canada. Available in $<$ http://www.cosewic.gc.ca/eng/sct0/assessment process_e.cfm>. Access on 13 June 2013.

Di Maio, F.R. 1996. Revisão taxonômica do gênero Hindsia Bentham (Rubiaceae,Hedyotideae). Arquivos do Jardim Botânico do Rio de Janeiro 34: 51-92.

Diamond, J.M. 1987. Extant unless proven extinct? Or, extinct unless proven extant? Conservation Biology 1:77-79.

Dinter, I. \& Werner, G. 2004. Silenerothmaleri (Caryophyllaceae), believed extinct, rediscovered at Cabo de São Vicente (Algarve, Portugal). Willdenowia 34: 371-380.

Echternacht, L.; Trovó, M. \& Sano, P.T. 2010. Rediscoveries in Eriocaulaceae: seven narrowly distributed taxa from the Espinhaço Range in Minas Gerais, Brazil. Feddes Repertorium 121: 117-126.

Environment protection and biodiversity conservation Act 1991. 2013. Australian government, ComLaw. Act No. 60. Available in $<$ http://www.comlaw.gov. $\mathrm{au} /$ Details/C2011C00014>. Access on 14 June 2013.

Filgueiras, T.S. \& Shirasuna, R.T. 2009. Redescoberta de espécies presumivelmente extintas de Poaceae da Flora de São Paulo, Brasil. Hoehnea 36: 507-509.

Foleuy, J.A.; DeFries, R.; Asner, G.P. Barford, C.; Bonan, G.; Carpenter, S.R.; Chapin, F.S.; Coe, M.T.; Daily, G.C.; Gibbs, H.K.; Helkowski, J.H.; Holloway, T.; Howard, E.A.; Kucharik, C.J.; Monfreda, C.; Patz, J.A.; Prentice, I.C.; Ramankutty, N. \& Snyder, P.K. 2005. Global consequences of land use. Science 309: 570-574.

Giulietti, A.M.; Andrade, M.J.G.; Trovó, M. \& Sano, P.T. 2009. Eriocaulaceae. In: Giulietti, A.M.; Rapini, A.; Andrade, M.J.G.; Queiroz, L.P. \& Silva, J.M.C. (eds.). Plantas raras do Brasil. Conservação Internacional, Universidade Estadual de Feira de Santana, Feira de Santana. Pp. 166-180.

Gonzalez, M. 2010. Análise das restrições de acesso a dados de espécies ameaçadas, previstas em políticas de coleções biológicas científicas brasileiras, à luz do direito ambiental e da ciência da informação. Ciência da Informação 39: 33-50.

Grammont, P.C. \& Cuarón, A.D. 2006. An evaluation of threatened species categorization systems used on the American continent. Conservation Biology 20: 14-27.

Granados-Tochoy, J.C.; Knapp, S. \& Orozco, C.I. 2007. Solanumhumboldtianum (Solanaceae): an endangered new species from Colombia rediscovered 200 Years after its first collection. Systematic Botany 32: 200-207. 
Hilton-Taylor, V.J.C. \& Stuart, S.N. (eds.). 2009. Wildlife in a Changing World - an analysis of the 2008 IUCN Red List of threatened species. IUCN, Gland. 180p.

IBAMA. 1992. Lista oficial de espécies da flora brasileira ameaçada de extinção. Anexo 2, Portaria n 37-N.

IUCN. 2001. IUCN Red list categories and criteria: version 3.1. IUCN Species Survival Commission. Available in <http://www.iucnredlist.org/static/ categories_criteria_3_1>.Access on 15 June 2013.

IUCN. 2010. IUCN Red list of threatened species. Version 8.1. Available in <www.iucnredlist.org $>$. Access on 12 June 2013.

Knapp, S. 2002. Solanum section Geminata (Solanaceae). Flora Neotropica Monograph 84: 1-404.

Kirschner J. \& Kaplan Z. 2002. Taxonomic monographs in relation to global Red Lists. Taxon 51: 155-158.

Leinz. V. \& Amaral, S. 1978. Geologia Geral. Companhia Editora Nacional, São Paulo. 397p

Leme, E.M.C. 2000. Nidularium. Bromélias da Mata Atlântica. Ed. Sextante, Rio de Janeiro. 264p.

Lomelí-Sención, J.A. \& Sahagún-Godínez, E. 2002. Rediscovery of Pedilanthus coalcomanensis (Euphorbiaceae), a threatened endemic mexican species. American Journal of Botany 89: 1485-1490.

Lok, A.F.S.L.; Ang, W.F.; Chong, K.Y. \& Tan, H.T.W. 2010. Rediscovery of Liparis barbata Lindl. (Orchidaceae) in Singapore. Nature in Singapore 3: 277-281.

Lok, A.F.S.L.; Tan, K.-x. \& Tan, H.T.W. 2008. Rediscovery of Dendrobium lobbii Teijsm. \& Binnend. (Orchidaceae) in Singapore. Nature in Singapore 1: 35-39.

Martinelli, G. \& Moraes, M. A. 2013. Livro Vermelho da Flora Brasileira. Andrea Jakobson Estúdio; Instituto de Pesquisas Jardim Botânico do Rio de Janeiro, Rio de Janeiro. 1100p.

Mendonça, M.P. \& Lins, L.V. 2000. Lista vermelha das espécies ameaçadas de extinção da flora de Minas Gerais. Fundação Biodiversitase Fundação Zoo-Botânica de Belo Horizonte, Belo Horizonte. $157 \mathrm{pp}$.

MMA - Ministério do Meio Ambiente. 2008. Instrução Normativa $N^{\circ} 6$ de 23/09/2008.

MMA - Ministério do Meio Ambiente. 2013. Espécies ameaçadas de extinção. Available in <www.mma. gov.br/biodiversidade/espécies-ameaçadas-deextinção>. Access on 10 July 2013.

Moraes, M.A. \& Martinelli,G. 2013. A importância de Listas Vermelhas nos processos de conservação da biodiversidade. In: Martinelli, G. \& Moraes, M.A. (eds.). Livro Vermelho da Flora Brasileira. Jardim Botânico do Rio de Janeiro, Rio de Janeiro. 1053p.

Pirani, J.R. \& Thomas, W.W.2013. Simaroubaceae. In: Lista de Espécies da Flora do Brasil. Jardim Botânico do Rio de Janeiro. Available in $<$ http://floradobrasil. jbrj.gov.br/jabot/floradobrasil/FB222>. Access on 15 June 2013.

Qiaoping, X.; FajonFls, A.; LI Zhenyu, L.; Likuo, F. \& Zhengyu, L. 2002. Thujasutchuenensis: a rediscovered species of the Cupressaceae. Botanical Journal of the Linnean Society 139: 305-310.

Sanbi - South African National Biodiversity Institute. 2013. Available in <http://www.sanbi.org/ news/crew-volunteers-rediscover-another-species $>$. Access on 12 June 2013.

Siqueira-Filho, J.A.; Santos, A.M.M.; Leme, E.M.C. \& Cabral, J.S. 2006. Fragmentos da Mata Atlântica de Pernambuco e Alagoas e suas bromélias: distribuição, composição riqueza e conservação. In: SiqueiraFilho, J.A. \& Leme, E.M.C. (eds.). Fragmentos de Mata Atlântica do Nordeste. Biodiversidade, conservação e suas bromélias. Andrea Jakobson Estúdio, Rio de Janeiro. Pp. 101-131.

Staden, L. von; Raimondo, D. \& Foden, W. 2009. Approach to Red List assessments. In: Raimondo, D.; Von Staden, L.; Foden,W.; Victor, J.E.; Helme, N.A.; Turner, R.C.; Kamundi, D.A. \& Manyama, P.A. (eds). Red List of South African Plants. South African National Biodiversity Institute, Pretoria. Pp. 6-18.

Sylvestre, L.S. 2001. Revisão taxonômica das espécies da família Aspleniaceae A. B. Frank ocorrentesno Brasil. Tese de Doutorado. Universidade de São Paulo, São Paulo. 571p.

Tabarelli, M. \& Gascon, C. 2005. Lições da pesquisa sobre fragmentação: aperfeiçoando políticas e diretrizes de manejo para a conservação da biodiversidade. Megadiversidade 1: 181-188.

Vasconcelos, M.F. \& Salino, A. 2002. A redescoberta de Huperzia rubra (Cham.) Trevisan (Lycopodiaceae) e o seu atual estado de conservação nas altas montanhas do sul da Cadeia do Espinhaço, Minas Gerais. Unimontes Científica 3: 45-50.

Wanderley, M.G.L.; Louzada, R.B.; Souza, G.M.; Lima, T.T. \& Versieux, L.M. 2009. Bromeliaceae. In: Giulietti, A.M.; Rapini, A.; Andrade, M.J.G.; Queiroz, L.P. \& Silva, J.M.C. (eds.). Plantas raras do Brasil. Conservação Internacional, Universidade Estadual de Feira de Santana, Feira de Santana. Pp. 103-114. 
